\title{
Words Matter. But Rights Matter More
}

\author{
Pia Oberoi
}

\section{Response to the ATR Debate Proposition: 'It is important and necessary to make clear distinctions between (irregular) migrants, refugees and trafficked persons.'}

Please cite this article as: P Oberoi, 'Words Matter. But Rights Matter More', Anti-Trafficking Review, issue 11, 2018, pp. 129-132, www.antitraffickingreview .org

The international community has recently taken steps to agree two intergovernmental compacts, which together are intended to revitalise the global governance of migration and asylum. ${ }^{1}$ The Global Compact on Refugees seeks to strengthen international cooperation on the refugee regime, while the Global Compact for Safe, Regular and Orderly Migration aims to establish principles, commitments and understandings among Member States regarding international migration in all its dimensions. The compacts have been brought into existence against a backdrop of widespread and increasingly systematic human rights violations committed against migrants by state officials, traffickers and other criminals, and leading to what has been called 'one of the greatest human tragedies of our time'. ${ }^{2}$ At the same time, the very bifurcation of the compacts into two 'separate, distinct and independent' 3 agreements rests on a set of assumptions that could distort rather than illuminate the complex issue of contemporary human mobility.

1 See: UN General Assembly, New York Declaration for Refugees and Migrants, 19 September 2016.

2 Report of the Special Rapporteur on torture and other cruel, inhuman degrading treatment or punishment, A/HRC/37/50, para. 64(a).

3 Modalities for the intergovernmental negotiations of the global compact for safe, regular and orderly migration, A/RES/71/280.

This is an open-access article distributed under the terms of the Creative Commons Attribution License (CC-BY). Under the CC-BY license, the public is free to share, adapt, and make commercial use of the work. Users must always give proper attribution to the authors and the Anti-Trafficking Review. 
One such underlying premise is that refugees are not migrants. While it is easy to agree with the proposition that refugees are refugees, i.e. people who have left their homes for fear of conflict or persecution, it is less straightforward to say that they are 'not migrants' for the simple reason that there is no universal legal understanding of the scope and content of the term 'migrant'. ${ }^{4}$ Further, the issues of identification, referrals and assistance of trafficked persons appear in both compacts, leading to additional confusion about whether trafficked persons are also considered refugees and/or 'migrants', and how the distinction being made between the two latter categories affects the protection space in the context of trafficking. And while the focus of the two compacts is specifically on cross-border movements, it is important to recall that trafficked persons often do not cross international borders. ${ }^{5}$

The bifurcation into oppositional categories of 'refugees' versus 'migrants' is further complicated by the complex human rights protection needs evident today. The United Nations Secretary-General has highlighted the plight of 'migrants in desperate situations, who are ineligible for refugee protection, yet who are particularly at risk.' A recent UN inter-agency initiative spearheaded by OHCHR notes that, 'where migrants fall outside the specific legal category

4 In the absence of a specific legal definition, the Office of the High Commissioner for Human Rights (OHCHR) simply understands an international migrant as 'any person who is outside a State of which they are a citizen or national, or, in the case of a stateless person, their State of birth or habitual residence'. This usage is without prejudice to the protection regimes that exist under international law for specific legal categories of non-nationals, including refugees, stateless persons, trafficked persons and migrant workers. See for example, Office of the High Commissioner for Human Rights and Global Migration Group, Principles and Guidelines, Supported by Practical Guidance, on the Human Rights Protection of Migrants in Vulnerable Situations, OHCHR/GMG, Geneva, 2018, retrieved 15 August 2018, https://www.ohchr.org/Documents/Issues/Migration/ PrinciplesAndGuidelines.pdf.

5 United Nations Office on Drugs and Crime, Global Report on Trafficking in Persons 2016, United Nations, Vienna, 2016, p. 9.

6 See para 47 of the Secretary-General's report Making Migration Work for All (A/ 72/643) available at https://refugeesmigrants.un.org/sites/default/files/ sg_report_en.pdf. In an earlier report, the Secretary-General also pointed out that 'notwithstanding the gradual expansion of refugee protection, many people are compelled to leave their homes for reasons that do not fall into the refugee definition' (A/70/59, para. 18). 
of "refugee", it may be especially important to ensure that their human rights are respected, protected and fulfilled. Some migrants will need specific protection because of the situations they left behind, the circumstances in which they travel or the conditions they face on arrival, or because of personal characteristics such as their age, gender identity, disability or health status. ${ }^{7}$ The emerging concept of 'migrants in vulnerable situations' makes clear that this vulnerability is not the result of a personal deficiency on the part of the migrant, and that being 'vulnerable' does not divest a person of agency or even resilience. 'Migrants in vulnerable situations' are people on the move in specific circumstances who are unable to effectively enjoy their human rights due to situations that are often-or usually_imposed on them by means of law, policy and practice. While these situations will not entitle them to refugee status, such migrants are at increased risk of human rights violations and abuse, and, consequently, are entitled to call on a duty bearer's heightened duty of care. ${ }^{8}$

Accordingly, my contention in response to the proposition of this debate, is that it is important and necessary to ensure that, regardless of categorisations, every person on the move is afforded the protection to which they are entitled under international law by virtue of their unique and individual circumstances. Such protection can be found in international refugee or human rights law, or in related standards including international labour or criminal law. The complex motivations for movement and the fluid, dangerous, long and multidirectional journeys taken by people on the move today require nuanced, contextualised and protection-sensitive responses. However, the necessity and suitability of defining this protection in antagonistic or oppositional terms is less clear and has even proven harmful; human rights protection is not a zero sum game. As the Global Compacts come into operation, it is important to challenge the assumption that there exists a finite amount of protection available only to those considered 'most deserving'.

International law clearly defines a refugee and is similarly specific in the definition of a trafficked person. The Global Compacts must build on these legally established and binding frameworks to ensure that the protection of the rights of refugees and the rights of trafficked persons are improved, not diminished. In addition, we can do better for migrants than defining them only as 'not refugees' or 'not victims of trafficking', especially when their need for human rights protection is often no less acute.

OHCHR and Global Migration Group, p. 1.

8 See resolution A/HRC/RES/35/17 of the Human Rights Council (June 2017). 
Migrants can be highly vulnerable to the most severe human rights violations, including arbitrary detention, collective expulsions, torture, family separation, denial of access to critical healthcare, and xenophobic violence, particularly when they are in irregular situations. This vulnerability is largely the result of specific migration governance paradigms, such as criminalisation of migration and mandatory or indefinite detention regimes, externalisation and securitisation of borders, a lack of safe and regular pathways, and entrenched precarity in labour migration. ' These responses to migration often make refugees and trafficked persons vulnerable to harm as well. States and other actors must reconsider a single-minded focus on distinctions, particularly where this may result in restricting the rights of those considered 'less deserving'. Instead, migration governance must prioritise and guarantee the universal protection of human rights law for all people on the move.

Pia Oberoi is Advisor on Migration and Human Rights at the Office of the United Nations High Commissioner for Human Rights where she heads the OHCHR Migration Team and leads OHCHR's global programme of work on policy and legal issues related to the intersections between migration and human rights. Prior to this, Pia led the migrant rights work of Amnesty International's International Secretariat. She holds a DPhil in International Relations from St Antony's College, Oxford University. This article is written in her personal capacity and the views expressed herein do not necessarily represent the views of the United Nations. Email: POberoi@ohchr.org.

9 See, in addition, the findings of the UN Special Rapporteur on Torture that 'The primary cause for the massive abuse suffered by migrants in all regions of the world ... is neither migration itself, nor organized crime, or the corruption of individual officials, but the growing tendency of States to base their official migration policies and practices on deterrence, criminalization and discrimination, rather than protection, human rights and non-discrimination.' (A/HRC/37/50, para. 64(d).) 